\title{
Covid-19: Why Germany's case fatality rate seems so low
}

\author{
Germany has the third highest number of coronavirus cases in Europe, but deaths are relatively \\ few when compared with neighbouring countries. Ned Stafford explains why
}

Ned Stafford freelance journalist

Hamburg, Germany

As the covid-19 pandemic continues to grow in severity, one of the most closely watched statistics has been Germany's number of deaths from the virus, which has been remarkably low in comparison with other nations, especially neighbouring European countries.

As of 2 April official statistics showed that 872 deaths from covid-19 had been recorded in Germany from 73522 confirmed cases, translating to a fatality rate of $1.2 \% .^{1}$ This compares with fatality rates of $11.9 \%$ in Italy, $9 \%$ in Spain, $8.6 \%$ in the Netherlands, $8 \%$ in the UK, and $7.1 \%$ in France. ${ }^{2}$

Christian Drosten, director of the Institute of Virology at the Charité hospital in Berlin, believes that Germany's relatively low covid-19 fatality rate can be attributed partly to the nation's early and high level of testing among a wide sample of the German population. While other countries were conducting a limited number of tests of older patients with severe cases of the virus, Germany was conducting many more tests that included milder cases in younger people.

The more tests are performed, the more likely it is that new cases will be found, and the higher total case numbers are relative to the proportion of cases that lead to death. Thus, the fatality rate decreases as this ratio widens.

Drosten, corresponding author of a January 2020 paper describing a reliable method for covid-19 testing, ${ }^{3}$ says that, under Germany's public health system, testing is not restricted to a central laboratory as in many other nations but can be conducted at quality controlled laboratories throughout the country.

"In this situation, it was easy for us to roll out a test protocol already in January," he says. "German labs are testing a lot. The overall capacity as of last week is likely to have exceeded half a million RT-PCR [reverse transcription polymerase chain reaction] tests."

Another possible explanation, says Drosten, is that many cases were imported into Germany by younger people who had been on ski holidays in Italy and Austria, although he emphasises that this is just a hypothesis. "We have not seen a lot of transmission in senior citizen homes or nosocomial outbreaks in hospitals," he says. "When this type of outbreak occurs, the age and fatality rate will be higher."

\section{Swift action}

Germany also took actions sooner than some other nations to stop the spread of covid-19. Initial actions were taken unilaterally by Germany's 16 states, led by Bavaria-its largest state and the hardest hit by covid-19. ${ }^{4}$ By mid-March states were closing schools and most retail businesses, as well as banning gatherings of people and mandating isolation of people who had covid-19 or were exposed to it.

On 22 March, after consulting state leaders, Chancellor Angela Merkel announced rules banning more than two people who lived in different households from being outside together. People who ventured out to supermarkets, pharmacies, doctor's offices, and banks also had to stay 1.5 to 2 metres apart. The great majority of people in Germany are voluntarily adhering to the contact restrictions, although there are, of course, exceptions.

Gérard Krause, head of the Department for Epidemiology at the Helmholtz Centre for Infection Research in Braunschweig, commented, "I support the current approach in Germany, which seems to be characterised more by appealing on compliance to rules rather than on enforcing them by micromanagement laws." $\mathrm{He}$ added, however, that some cities and federal states were now exploring legal enforcement.

\section{Caution urged}

Concern is growing that the relatively low fatality rate may be "the calm before the storm," as the German health minister Jens Spahn has put it. ${ }^{5}$ Drosten warns that the apparent case fatality may not stay this low, while Krause says that "we may still be at the very beginning of the wave compared to other countries." 
There are worrying signs of acceleration. The Robert Koch Institute's daily covid-19 report on 26 March showed a total of 149 deaths, meaning a fatality rate of $0.5 \%$. In the following days the death rate edged higher, doubling from 66 deaths on 30 March to 128 the next day. The 1 April report showed 149 new deaths (a total of 732 and a $1.1 \%$ fatality rate).

Krause, whose research team is investigating whether patients who recover from covid-19 are immune to reinfection, ${ }^{6}$ thinks that the question is not whether Germany has done enough to fight covid-19 but whether it has done the right things.

He explains, "Additional action with respect to equipment and protection of medical staff and protection of individuals with high risk for severe disease would certainly be a good investment. In such a situation, it is probably impossible to have done enough."

Competing interests: I have read and understood BMJ policy on declaration of interests and have no relevant interests to declare.
Provenance and peer review: Commissioned; not externally peer reviewed.

1 Robert Koch Institute. Current situation report by the Robert Koch Institute on COVID-19 (with archive). 2020. https://www.rki.de/DE/Content/InfAZ/N/Neuartiges_Coronavirus/ Situationsberichte/Gesamt.html. (In German and English.)

2 Statista. Coronavirus (COVID-19) death rate in countries with confirmed deaths and ove 1000 reported cases as of April 3, 2020, by country. Apr 2020. https://www.statista.com/ statistics/1105914/coronavirus-death-rates-worldwide/.

3 Corman VM, Landt O, Kaiser M, et al. Detection of 2019 novel coronavirus (2019-nCoV) by real-time RT-PCR. Euro Surveill 2020;25:pii=2000045. .

4 Robert Koch Institute. Covid-19 dashboard. 2020. https://experience.arcgis.com/ experience/478220a4c454480e823b17327b2bf1d4. (In German.)

5 Spahn spricht von "Ruhe vor dem Sturm" [Spahn speaks of "calm before the storm"] Spiegel 2020 Mar 26. https://www.spiegel.de/politik/deutschland/coronavirus-spahnspricht-von-ruhe-vor-dem-sturm-a-5c0e995d-1782-4c6e-9251-90211fa2bae8. (In German, translatable to English.)

6 Helmholtz Centre for Infection Research. HZl coordinates project on the prevalence of coronavirus antibodies. $27 \mathrm{Mar}$ 2020. https://www.helmholtz-hzi.de/en/news-events/news/ view/article/complete/bevoelkerungsstudie-untersucht-immunitaet-gegen-covid-19/.

Published by the BMJ Publishing Group Limited. For permission to use (where not already granted under a licence) please go to http://group.bmj.com/group/rights-licensing/ permissions 